\title{
TBM in Azad Kashmir region of Pakistan: in situ stress measurements for rockburst prevision
}

Riccardo Amici MSc (Hons), BSc, CGeol, FGS, FHKMA, PMI Principal Engineer Tunnels, Multiconsult, Oslo, Norway (corresponding author: riccamici@gmail.com) (Orcid:0000-0002-1257-7419)

Gary Peach CEng

Resident Engineer TBM, Multiconsult, Oslo, Norway

\author{
Mohammed Nadeem \\ Assistant Resident Engineer Geology TBM, National Development \\ Consultants, Lahore, Pakistan
}

\begin{abstract}
Using the authors' experience, this paper details the in situ stress measurements in twin tunnel boring machine (TBM) tunnels of the Neelum Jhelum hydropower project, located in the Azad Kashmir region of north-east Pakistan in foothills of the Himalayas, with overburdens up to $2000 \mathrm{~m}$ and high tectonic stresses in very complex geology. The ability to predict the likelihood, location, severity and number of rockbursts directly impacts on the tunnel safety and daily production rates. This, combined with the lack of previous project experience in similar conditions, has required the use of all the available advanced geological prediction methods: forward probing, tunnel seismic tomography, continuous microseismic monitoring and in situ stress measurements were used. These methods, except in situ stress measurements, only gave an indication of likelihood and severity of rockbursts. The in situ tests provided the actual ground stresses and their orientations. The in situ stress results contradicted the forecasts based on the classical empirical rules combining stress analysis and rock strength. This paper is focused on the in situ stress measurements carried out behind the two TBMs and details the information obtained and how data were interpreted and integrated to support excavation, prevention and control of rockbursts, which improved tunnel safety and productivity.
\end{abstract}

\section{Introduction}

The Neelum Jhelum hydroelectric project is located in the Muzaffarabad district of Azad Jammu and Kashmir, a northeastern area of Pakistan. The headrace tunnel is designed to extend between the Neelum and Jhelum Rivers. The hydroelectric project will have an installed capacity of $969 \mathrm{MW}$ and a head of $420 \mathrm{~m}$. It is a long-tunnel-diversion-type hydropower scheme. A map illustrating the complete north-east-south-west-directed conveyance scheme is shown in Figure 1.

\section{Project background}

No previous tunnelling projects or hydroelectric projects of this scale have been constructed in Pakistan, and none have been constructed with relevant tunnel boring machine (TBM) methods.

\section{Geological rock types}

Baseline underground conditions including descriptions of expected rock types, their characteristics and quality have been established based on the engineering geology of the headrace tunnel as provided in the detailed design report by Norconsult (1997).

The geology in the TBM section is characterised by a folded, heavily tectonised sedimentary sequence belonging to the Lower Murree Formation. This formation consists mainly of sandstone and shale units that have undergone low-grade metamorphism. Along the planned TBM tunnel section, a consistent interbedding of sandstone, siltstone and mudstone layers was anticipated. Such strata are widely exposed with hundreds of metres thickness in the project area.
The rock sequence is tightly folded and heavily tectonised and has undergone repeated deformations. Sandstone units are typically prominently jointed and mudstones exhibit internal shearing. The project is located in a tectonically active region.

The rocks encountered in the tunnels are described mainly as sandstones (SS-I), siltstones and silty sandstones (SS-II) and mudstones (MST).

\section{Lithology}

SANDSTONES (SS-I)

These are the strongest members of the Murree sequence. They are usually grey, with sharply defined contacts, and $34 \%$ of the TBM tunnels have been excavated in this material. Bedding thicknesses vary from a few metres to over $50 \mathrm{~m}$. Of 30 samples tested during excavation, $77 \%$ samples were in the $130-170 \mathrm{MPa}$ range, whereas the remaining $23 \%$ exhibited higher strengths, up to $230 \mathrm{MPa}$.

\section{SILTSTONES AND SILTY SANDSTONES (SS-II)}

A suite of light reddish-brown siltstones that grade to silty sandstones constitutes the most commonly occurring rock type on the project, with about $65 \%$ of the TBM tunnels excavated in this unit. Typical uniaxial compressive strengths (UCSs) are 50-70 MPa.

\section{MUDSTONES (MST)}

Mudstones, which also are invariably dark reddish brown, represent the weakest rocks in the Murree sequence, with UCSs in 


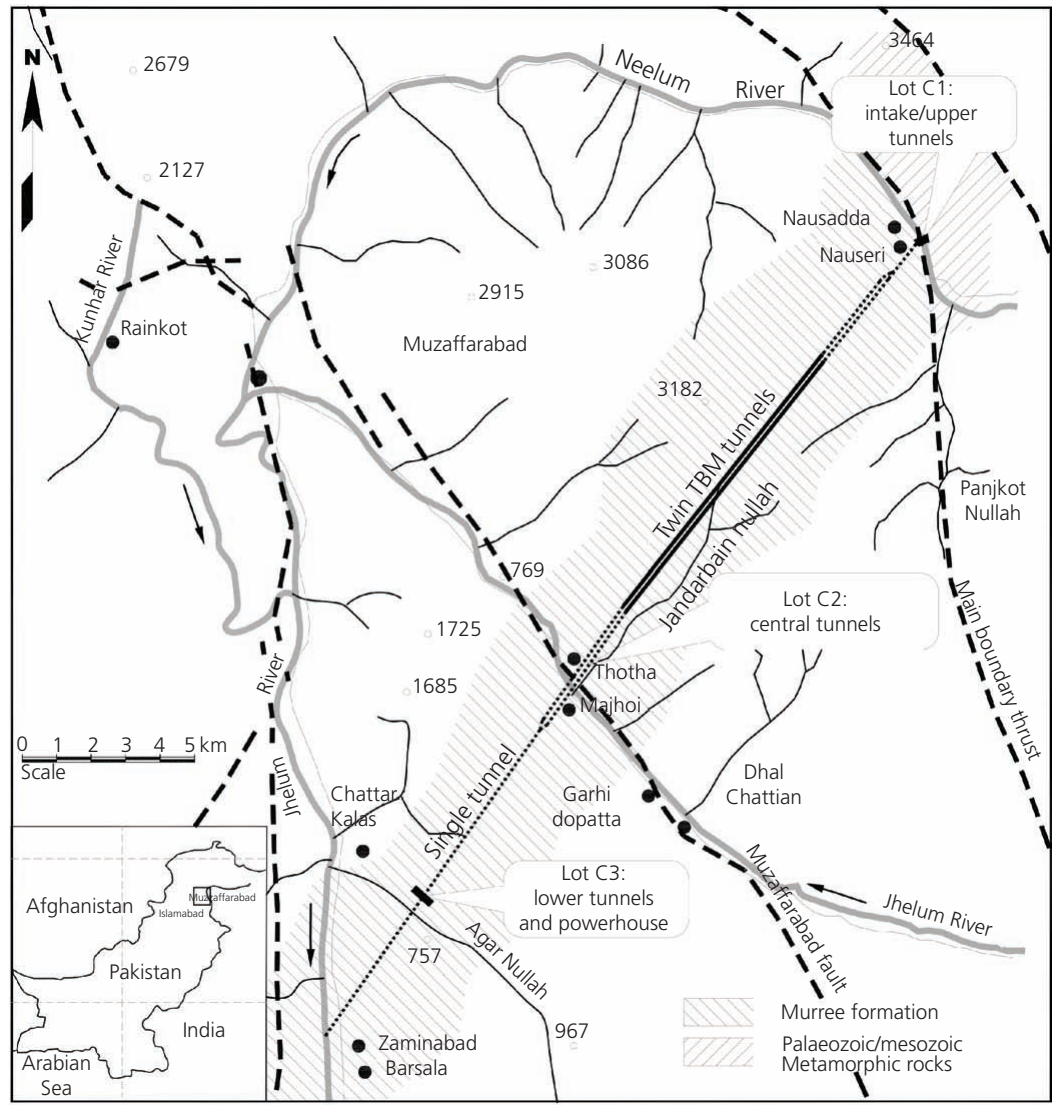

Figure 1. Project layout showing TBM twin tunnels (thick solid lines), major faults (dashed lines) and simplified alignment geology

the $30-40 \mathrm{MPa}$ range, and accounted for only $1 \%$ of the TBMexcavated tunnels.

\section{Geological structures and conditions}

In addition to the expected rock types detailed earlier, there were also certain ground conditions which are expected to be encountered and with which the TBM was designed to manage. Also, the TBM should have further facilities to detect in advance these conditions, in order to take appropriate measures to negotiate successfully the identified conditions. These structures and conditions included

- unstable rock zones

- squeezing and swelling ground

- soft ground

- high water inflows

- extensive fault zones

rockbursts

- high overburden depths (2000 m).

\section{TBM selection}

Of the headrace tunnel system, $20 \mathrm{~km}$ was excavated by TBMs in two parallel tunnels. Two open (gripper) TBMs were used to excavate this tunnel system.
The type of TBM was selected after evaluating the most up-todate TBM designs and, more importantly, successful application of TBM technology in the same or similar ground conditions worldwide. The successful application of TBMs in similar ground conditions was demonstrated by those of the Gotthard Base Tunnel in Switzerland. Here, very similar open-type (gripper-type) TBMs excavated $85 \mathrm{~km}$ of the $157 \mathrm{~km}$ rail tunnel system.

A significant consideration for the TBM selection was the possibility of encountering squeezing ground, with deformations of up to $500 \mathrm{~mm}$ on the tunnel diameter. This would exclude many types of TBM designs due to the possibility of becoming trapped within the tunnel. The open (gripper) TBM is best suited to deal with this potential condition, due to the short length of the front shield and its ability to collapse inwards various sections of the front shield, depending on ground conditions, and still maintain the ability to excavate forward.

The second ground condition which was indicated to be present in the higher overburdens and more brittle rock was rockbursting. Again, the open gripper TBM configuration allows equipment to be installed to detect and mitigate potential rockbursts. The same TBM manufacturer responsible for four of the TBMs used so successfully on the Gotthard Base Tunnel was selected after 
TBM in Azad Kashmir region of Pakistan: in situ stress measurements for rockburst prevision

Amici, Peach and Nadeem

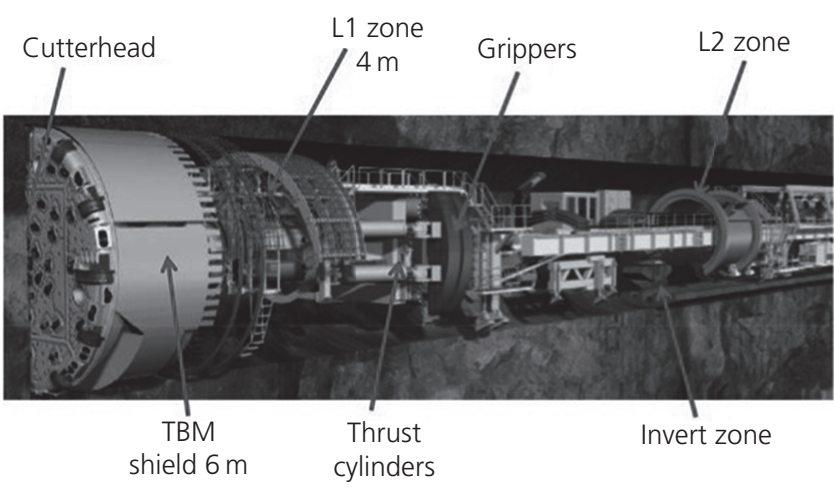

Figure 2. General arrangement of open gripper TBM (courtesy of Herrenknecht)

tender evaluations to supply the two TBMs for the Neelum Jhelum project.

The designed tunnel excavation diameter is $8.5 \mathrm{~m}$, giving a total face area of $56.75 \mathrm{~m}^{2}$. The tunnel gradient is ascending from south-west to north-east.

\section{Cutterhead and front shield}

The general arrangement of the open gripper TBM is shown in Figure 2. The cutterhead is the only solid component and is connected to the front shield.

\section{Tunnel support equipment (L1)}

Each TBM was equipped with the following equipment for support installation in the L1 location, which was $3.5 \mathrm{~m}$ immediately behind the rear of the cutterhead shield. Rock bolts were installed using twin rock drills mounted on a circular track system which gave a radial coverage for the top $260^{\circ}$ of the tunnel periphery. Wire mesh was installed by way of a mesherecting device, which lifted the mesh into position on the tunnel circumference, and then secured by way of rock bolts. In poor ground conditions, the TBM could erect full circular steel rings by using an erector installed within the TBM shield. Shotcrete could then be applied if required by way of a mobile shotcrete spray arm over the top $200^{\circ}$ of the excavated tunnel.

\section{Tunnel support equipment (L2)}

The $\mathrm{L} 2$ section is $60 \mathrm{~m}$ behind the $\mathrm{L} 1$ section. In this zone, a duplicate set of rock bolting equipment was installed, with a slightly reduced radial coverage due to the installation of rail track. Immediately behind the rock bolting equipment is the permanent shotcrete lining equipment; this consists of two spray robots, each mounted on a longitudinal track allowing a $7 \mathrm{~m}$ travel distance laterally along the tunnel and a radial coverage of $270^{\circ}$ of the tunnel crown.

\section{Rockburst}

The Canadian Rockburst Support Handbook defines rockbursts as 'damage to an excavation that occurs in a sudden or violent manner and is associated with a seismic event' (Kaiser et al., 1996: p. 131). This definition for rockburst was deemed too restrictive for the Neelum Jhelum project. The term 'rockburst' was expanded to refer to any release of detectable energy linked with TBM excavation.

Rockbursts can be self-initiated or remotely triggered. Selfinitiated rockbursts occur when tangential stresses near the excavation boundary exceed the rock mass strength and failure proceeds in an unstable or violent manner (Kaiser et al., 1996). Once the stresses exceed the strength of the rock mass, it can violently and suddenly fracture. Figure 3 shows different rockburst damage mechanisms induced by seismic energy or otherwise.

The rockbursts which occurred during the TBM excavation are the first type, self-initiated or strain burst, due to the fracturing of the rock around the excavation. Fracturing and dilation occur when the stresses near the opening exceed the rock mass strength, triggering a violent release of excess energy. The primary source of energy causing fracturing and dilation comes from the strain energy stored in the rock around the opening (Kaiser and McCreath, 1993).

Rockbursts were first encountered in deep mines, and much of the rockburst literature comes from the mining industry. Traditional mining methods such as drilling and blasting do not require high concentrations of plant and equipment present near the excavation face. This contrasts with TBM excavation, which continually concentrates complex equipment and manpower close to the excavation face.

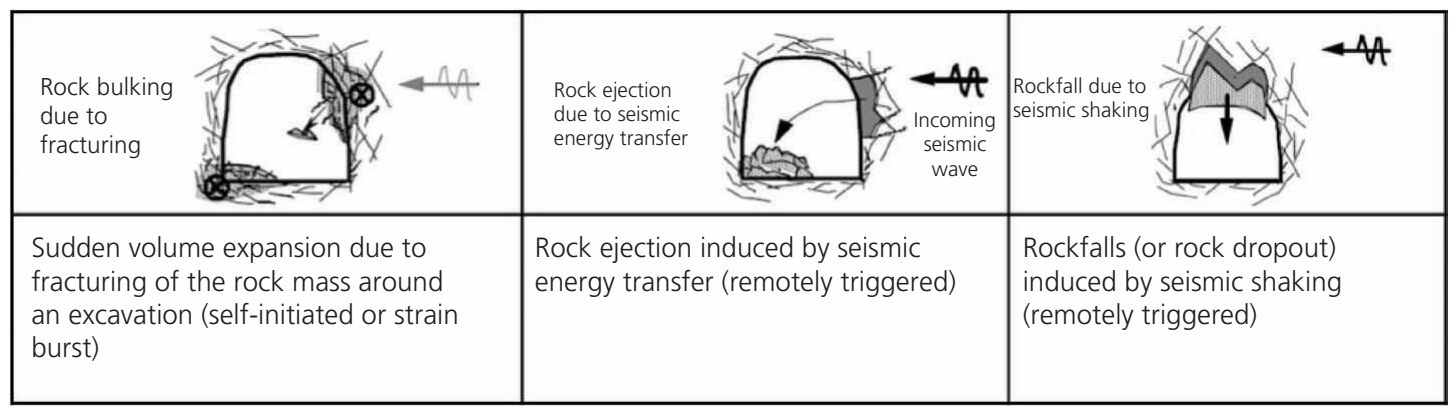

Figure 3. Rockburst damage mechanisms (from Kaiser et al. (1996)) 


\section{TBM advance ground investigation equipment}

The previous sections give a comprehensive outline of the rock types and ground conditions that were expected on the Neelum Jhelum project. The TBMs have been designed to have equipment and facilities to manage and mitigate these ground conditions as far as practical.

It is preferable that any information on potential adverse ground conditions is obtained as far in advance of the TBM encountering the feature as possible. This will allow time to assess the situation and take predetermined countermeasures or contingency measures. These will ultimately allow the TBM to transverse the adverse condition in the most efficient manner possible, causing minimal impact on tunnel progress.

With this in mind, initially both TBMs were equipped with two separate and independent systems for carrying out advance ground investigation. These were

- probe drilling

- tunnel seismic tomography (TST) system.

Later in the project when the rockburst zones were encountered, additional ground investigation systems were used in each TBM tunnel; these were

- rockburst prediction using uniaxial compressive strength

- microseismic monitoring.

In Figure 4, the lower section shows the twin TBM tunnel alignment, while the upper portion shows the relative overburden along the tunnel alignment. Overlain on the tunnel alignment is the location over which each of the above ground investigation systems was deployed. Figure 4 also identifies the two separate TBM tunnels. Each tunnel is identified by the TBM manufacturing number of the TBM within that tunnel. The two TBM numbers are TBM 696 and TBM 697, and this naming will be used within this paper. For completeness, TBM 697 was the lead TBM throughout the project and TBM 696 experienced a severe rockburst which immobilised it for $7 \cdot 5$ months.

The four investigation techniques mentioned above all gave valuable advance geological conditions in front of each TBM. However, no one system provided a full picture of what was ahead. The advance probe hole $(30-40 \mathrm{~m})$ could identify sandstone beds, but would not give an indication of potential rockbursts. The TST would again give an indication of changes in rock integrity up to $110 \mathrm{~m}$ in advance, which would help target the probe locations. The rockburst prediction using UCS was time consuming and often unclear. The microseismic monitoring took a considerable time to install but would give indications of rockburst likelihood and severity.

What the advance ground investigation programme required was the measurement and information of actual ground stresses along the TBM tunnel alignment. Therefore, a fifth technique was decided on and implemented, namely, coring for in situ stress.

\section{Rockburst prediction using empirical rules combining stress analysis and rock strength}

The prediction of severity of rockburst and depth of spalling was attempted using empirical rules combining stress analysis and rock strength, introduced by Grimstad and Barton (1993) and Nicksiar and Martin (2013). Diederichs et al. (2010) suggested a correlation to predict the depth of spalling.

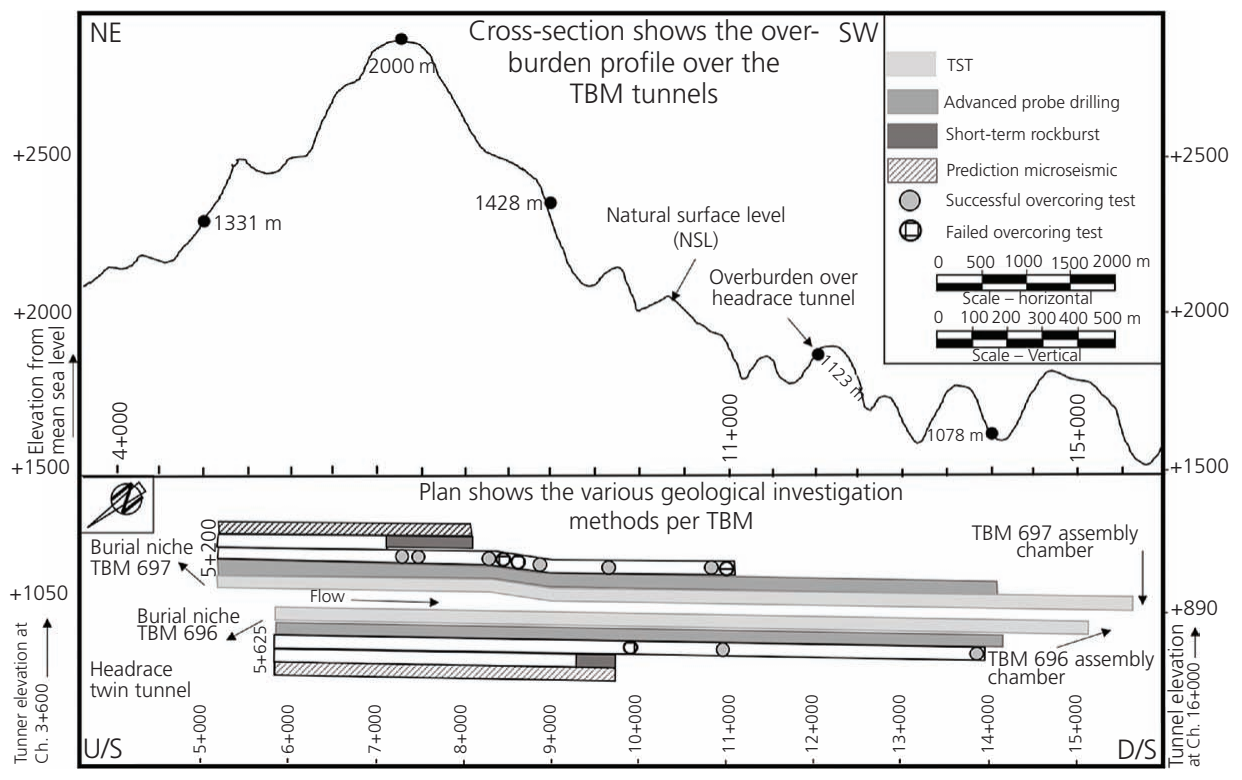

Figure 4. TBM tunnel alignment and overburden with locations of ground investigation systems. Ch., chainage; D/S downstream; U/S upstream 
Table 1. Rockburst severity classification according to the NGI Q-system

\begin{tabular}{|c|c|c|c|}
\hline $\begin{array}{l}\text { Competent, mainly massive rock, } \\
\text { stress problems }\end{array}$ & $\sigma_{\mathrm{c}} / \sigma_{1}$ & $\sigma_{\theta} / \sigma_{\mathrm{c}}$ & SRF \\
\hline $\begin{array}{l}\text { F Low stress, near surface, open } \\
\text { joints }\end{array}$ & $>200$ & $<0.01$ & $2 \cdot 5$ \\
\hline $\begin{array}{l}\text { G Medium stress, favourable stress } \\
\text { condition }\end{array}$ & 200-10 & $0.01-0.3$ & 1 \\
\hline $\begin{array}{l}\text { H High stress, very tight structure. } \\
\text { Usually favourable to stability. } \\
\text { May also be unfavourable to } \\
\text { stability dependent on the } \\
\text { orientation of stress compared } \\
\text { to jointing/weakness planes* }\end{array}$ & $10-5$ & $0.3-0.4$ & $\begin{array}{r}0 \cdot 5-5 \\
2-5^{*}\end{array}$ \\
\hline $\begin{array}{l}\text { Moderate spalling and/or } \\
\text { slabbing after }>1 \mathrm{~h} \text { in massive } \\
\text { rock }\end{array}$ & $5-3$ & $0.5-0.65$ & $5 \cdot 50$ \\
\hline $\begin{array}{l}\text { K Spalling or rockburst after a few } \\
\text { minutes in massive rock }\end{array}$ & $3-2$ & $0.65-1$ & $50-200$ \\
\hline $\begin{array}{l}\text { L Heavy rockburst and immediate } \\
\text { dynamic deformation in } \\
\text { massive rock }\end{array}$ & $<2$ & $>1$ & $200-400$ \\
\hline
\end{tabular}

Using the UCS from laboratory testing, combined with estimated confidence intervals and stress magnitudes, the prediction of rockburst severity and depth of spalling was attempted for sandstone. This prediction shows that moderate spalling was expected for overburdens of 1000-1300 m, mainly located in the crown and invert, with a depth of spalling between 1.5 and $1.8 \mathrm{~m}$. With overburden above $1300 \mathrm{~m}$, serious rockburst incidents were predictable in the walls, with depth of spalling between $2 \cdot 1$ and $3 \cdot 8 \mathrm{~m}$.

The severity of rockburst is classified according to the criterion in Table 1, using the ratio between rock UCS and tangential stress. The empirical rule is used to convey the gravitational rock stress to tangential rock stress. It can be seen that the rockburst occurrence is directly related to the overburden. The heavy rockburst was expected where overburden is greater than $1600 \mathrm{~m}$. Prediction of rockburst according to Grimstad and Barton (1993) is shown in Table 2.

\section{Principle of in situ stress tests by hollow inclusion method and biaxial tests}

The hollow inclusion (HI) measures strains during and after an overcoring process, which is shown in Figure 5.

Table 2. Prediction of rockburst based on Grimstad and Barton (1993) using gravitational stress and rock UCS with various assumed $k_{0}$ values and overburden

\begin{tabular}{|c|c|c|c|c|c|c|}
\hline \multirow{3}{*}{ Overburden: $\mathrm{m}$} & \multirow{3}{*}{ Vertical stress, $\sigma_{2}: \mathrm{MPa}$} & \multirow{3}{*}{$k_{0}$} & \multicolumn{4}{|c|}{ Prediction of rockburst in Q2 SS-1 sandstone } \\
\hline & & & \multirow{2}{*}{$\frac{\sigma_{0} / \sigma_{\mathrm{c}}}{\text { Roof }}$} & \multirow{2}{*}{$\frac{\sigma_{0} / \sigma_{\mathrm{c}}}{\text { Wall }}$} & \multicolumn{2}{|c|}{ Assumed rockburst } \\
\hline & & & & & Roof & Wall \\
\hline 1100 & $29 \cdot 7$ & $1 \cdot 1$ & 0.79 & 0.66 & Slabbing/rockburst & Slabbing/rockburst \\
\hline 1200 & $32 \cdot 4$ & $1 \cdot 1$ & 0.87 & $0 \cdot 72$ & Slabbing/rockburst & Slabbing/rockburst \\
\hline 1300 & $35 \cdot 1$ & $1 \cdot 0$ & 0.82 & 0.82 & Slabbing/rockburst & Slabbing/rockburst \\
\hline 1400 & $37 \cdot 8$ & 1.0 & 0.88 & 0.88 & Slabbing/rockburst & Slabbing/rockburst \\
\hline 1500 & $40 \cdot 5$ & 0.9 & 0.80 & 0.99 & Slabbing/rockburst & Slabbing/rockburst \\
\hline 1600 & $43 \cdot 2$ & 0.9 & 0.85 & 1.05 & Slabbing/rockburst & Heavy rockburst \\
\hline 1700 & $45 \cdot 9$ & 0.9 & 0.91 & $1 \cdot 12$ & Slabbing/rockburst & Heavy rockburst \\
\hline 1800 & $48 \cdot 6$ & $0 \cdot 8$ & 0.79 & $1 \cdot 24$ & Slabbing/rockburst & Heavy rockburst \\
\hline 1850 & $50 \cdot 0$ & 0.8 & 0.81 & $1 \cdot 28$ & Slabbing/rockburst & Heavy rockburst \\
\hline
\end{tabular}

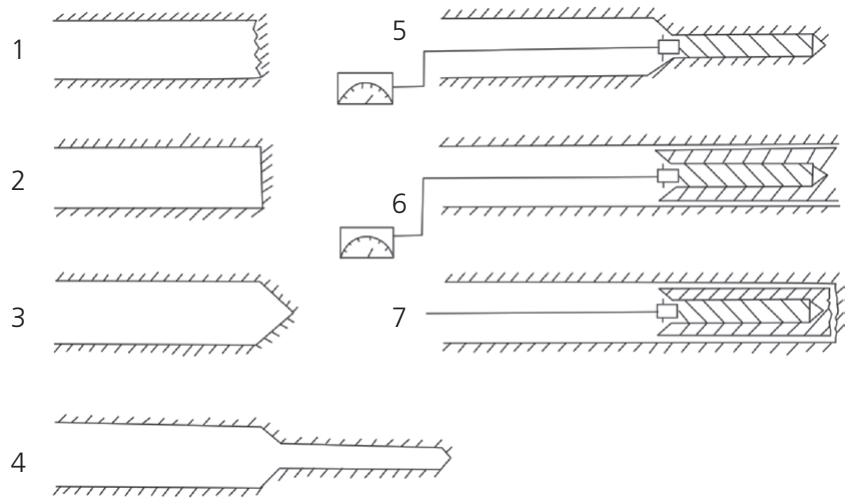

Figure 5. Commonwealth Scientific and Industrial Research Organisation (Csiro) HI cell test procedures for drilling, installation and measurement. 1, drill a $130 \mathrm{~mm}$ dia. borehole; 2, grind the end face of the borehole; 3, drill a trumpet on the end face of the main hole; 4, drill a $38 \mathrm{~mm}$ dia. borehole; 5 , install the stress gauge; 6 , overcore the borehole and measure the strain changes in the borehole; 7, break the core and take it out of the hole 
TBM in Azad Kashmir region of Pakistan: in situ stress measurements for rockburst prevision

Amici, Peach and Nadeem
From these strains, stresses can be calculated by applying Hoek and Brown's law (Hoek and Brown, 1980). The elastic properties of the rock are obtained from a biaxial test on the overcored specimen. The HI incorporates 12 strain gauges within an epoxy shell (Figures 6 and 7). The cell is grouted into a borehole and overcored. This overcoring process isolates the rock surrounding the cell (i.e. distresses it), resulting in the rock annulus changing shape in all directions according to the amount of stress that it was originally accepting and the material properties of the rock annulus. Assuming that a linear elastic behaviour occurs, the strain gauge readings during overcoring are a function of the original in situ rock stress. With the measured strains and rock material properties, the three-dimensional stress tensor expressed in terms of principal stress and orientations can be obtained (Worotnicki and Walton, 1976).

Commonwealth Scientific and Industrial Research Organisation (Csiro) HI overcoring tests were planned in the TBM tunnels to assess the underground rock stresses at different locations. The Institute of Rock and Soil Mechanics in China performed overcoring tests in the Neelum Jhelum TBM tunnels.

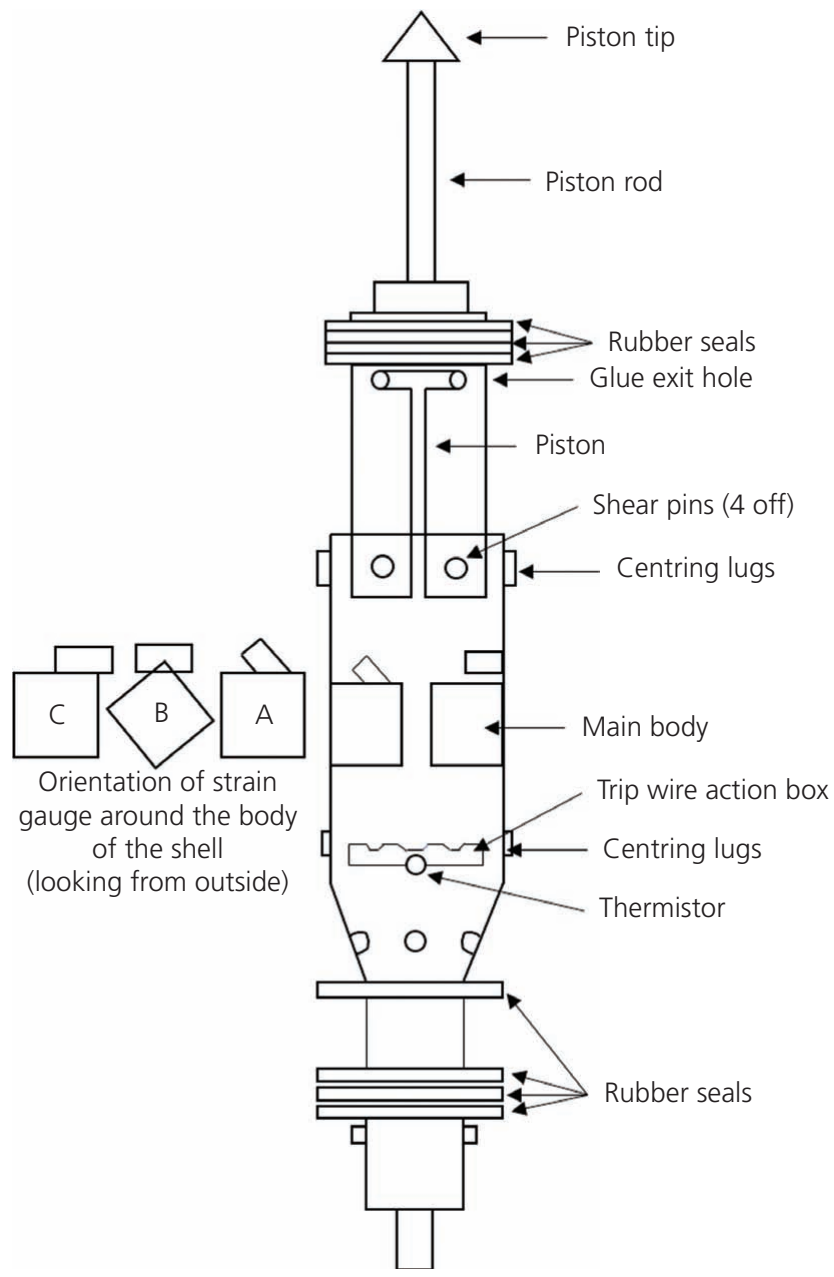

Figure 6. The different components of the Csiro HI cell

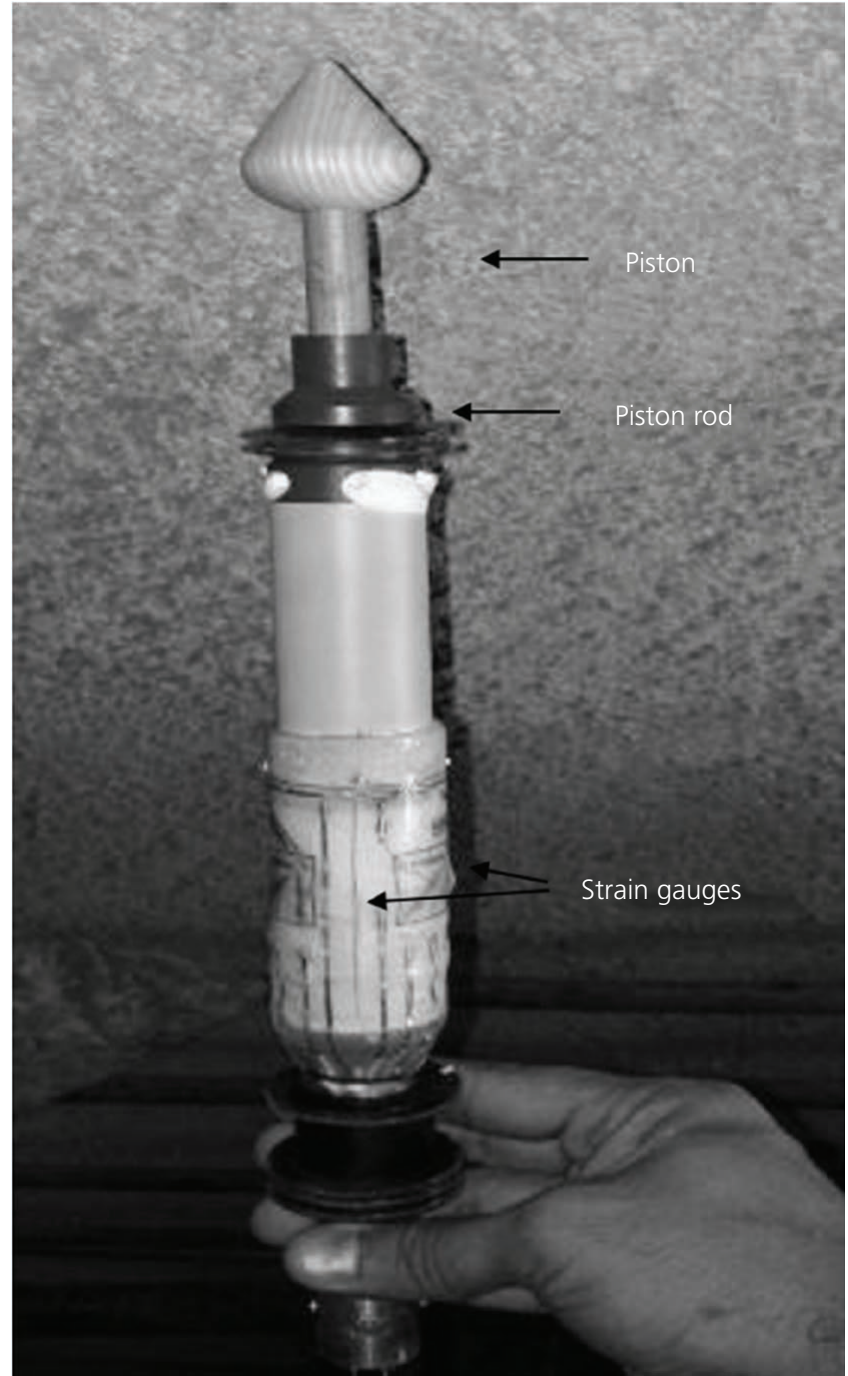

Figure 7. The HI cell used for tests

Twelve overcoring tests were planned in the TBM tunnels to assess the underground rock stresses at different locations. Initially three locations with major rockbursts from sandstone in each TBM were selected for the tests. After that, four locations in sandstone from TBM 697 were selected under different overburdens to check the relationship between overburden and underground stresses. One location for the overcoring test was selected from siltstone and one from mudstone in TBM 697. Three tests were performed at each location in the borehole. The depth of the overcoring test in the borehole was beyond $17 \mathrm{~m}$, which was twice the diameter of the tunnel. Each overcoring test required a $0.5 \mathrm{~m}$ section in the borehole.

\section{Instrument used for stress measurement}

The HI cell (Csiro HI cell) measures strain during and after the overcoring test. During the overcoring test in the borehole, 12 strain gauges are placed over the HI cell and the strain is read, which is recorded on a laptop. The elastic properties of the rock are measured with the help of biaxial test on the overcore specimen 
TBM in Azad Kashmir region of Pakistan: in situ stress measurements for rockburst prevision

Amici, Peach and Nadeem
(Figure 8). From these strain data, the stresses can be calculated by applying Hoek and Brown's law (Hoek and Brown, 1980).

\section{Core discing}

Core discing was regularly observed during drilling of the sandstone borehole in both TBMs at different locations and under different overburdens (Figures 9 and 10). It is a process in which drilled core separates discs with uniform spacing and shape. Core discing shows high stresses in the borehole, which are released during drilling of the core. It is considered that the boreholes in which core discing was observed have more stresses compared with the borehole where core discing was not observed and $\mathrm{HI}$ overcoring tests performed successfully.

In TBM 697, four boreholes were terminated due to core discing at chainages $10+934,10+935,10+936$ and $08+422$, whereas in TBM 696, one borehole was terminated due to core discing from chainage $09+860 \cdot 8$. In all these boreholes, the core discing starts

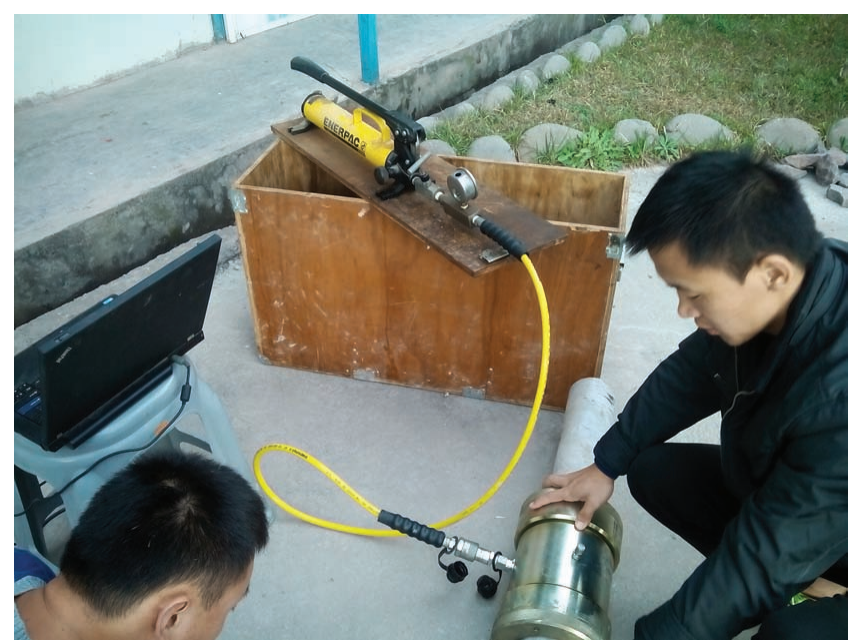

Figure 8. Biaxial test after overcoring test on the specimen

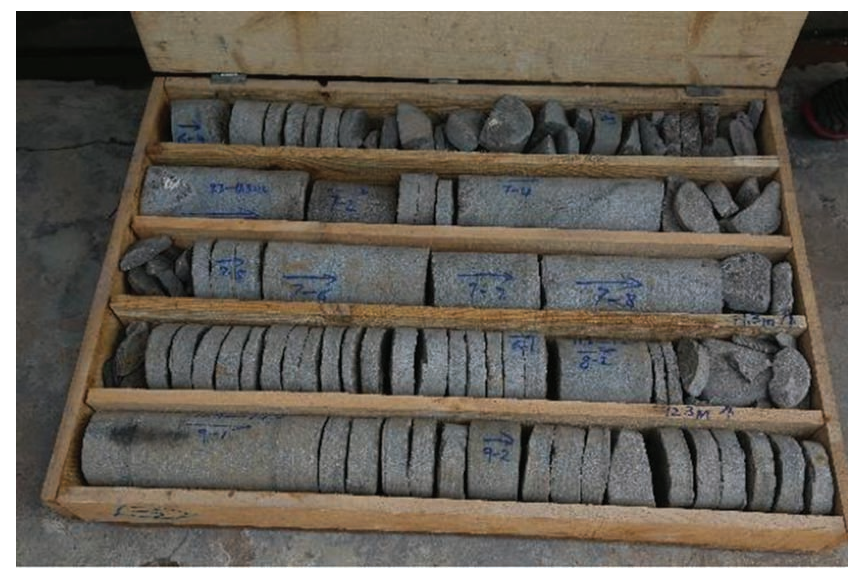

Figure 9. Core discing in the borehole drill at chainage $09+860 \cdot 8$ in TBM 696

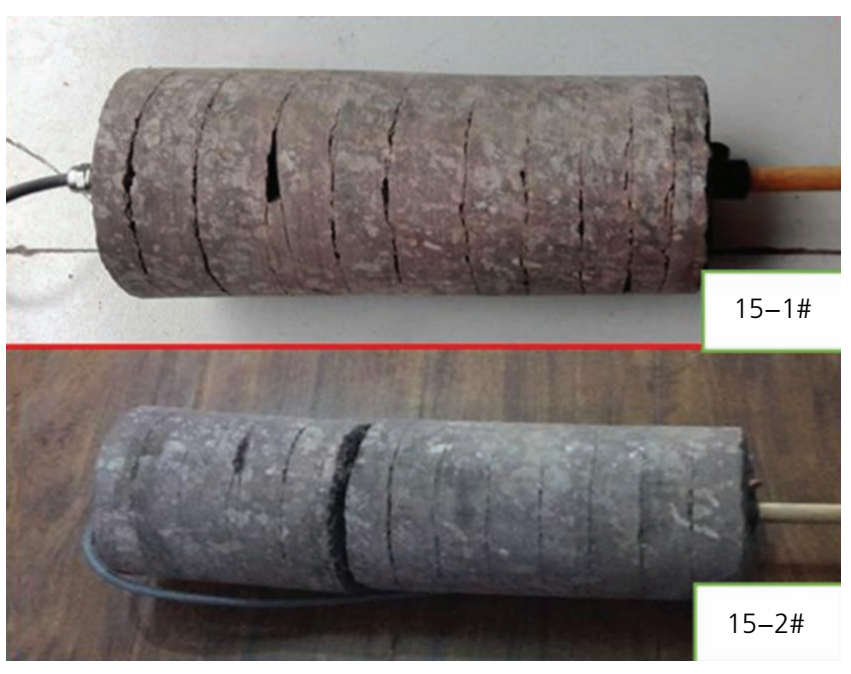

Figure 10. Examples of discing after overcoring at chainage $07+280$ in TBM 697

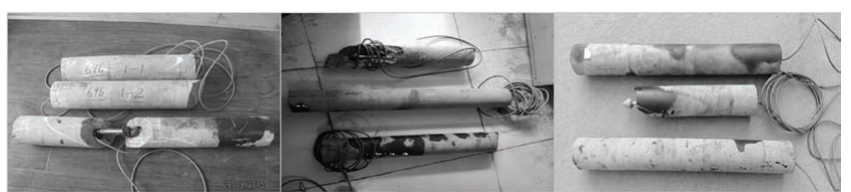

Figure 11. Examples of good cores obtained

from depth ranges from 10 to $14 \mathrm{~m}$ and continues up to the end of the hole. In the other boreholes, the overcore sample was recovered successfully (Figure 11).

\section{Overcoring test results}

The results obtained from the overcoring tests are detailed in Table 3. During all these overcoring tests, microstrain was recorded with the help of a cable from the borehole. Biaxial tests were carried out on the overcore sample to obtain the accurate values of the elastic modulus and Poisson's ratio. During the biaxial test, the applied stresses increased from 0 to $20 \mathrm{MPa}$ with an interval of $5 \mathrm{MPa}$ and then unloaded to $0 \mathrm{MPa}$ gradually.

The in situ stresses obtained from the overcoring and biaxial test are $\sigma_{1}, \sigma_{2}$ and $\sigma_{3}$ (Table 3). When the in situ stresses located at the local coordinate of the tunnel (Figure 12, $X$ perpendicular to the tunnel axis, $Y$ the axis of tunnel and $Z$ the direction of gravity), then the six stress components $(X, Y, Z, X-Y, X-Z, Z-Y)$ are shown in Table 3.

\section{Practical application of stress information}

The results of the HI overcoring tests (Table 3) show the presence of very high stress in the investigated area with maximum principal stress of up to $110 \mathrm{MPa}$. In Figure 13, the field stresses obtained from the in situ measurements are plotted against the overburden. It can be noted that, except for $\sigma_{2}$, the stresses are not strongly related to the tunnel depth. In Figure 14, the stresses 


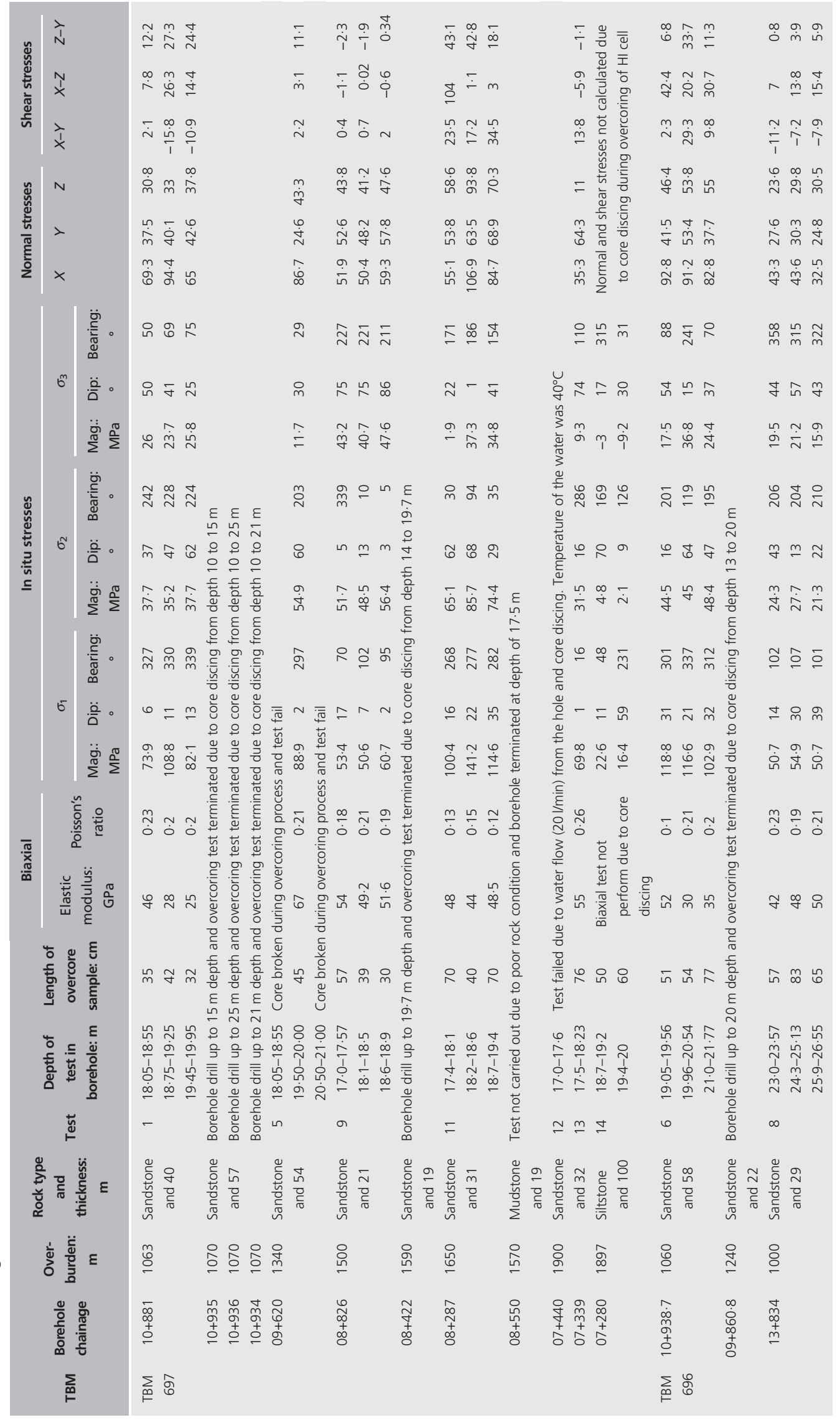




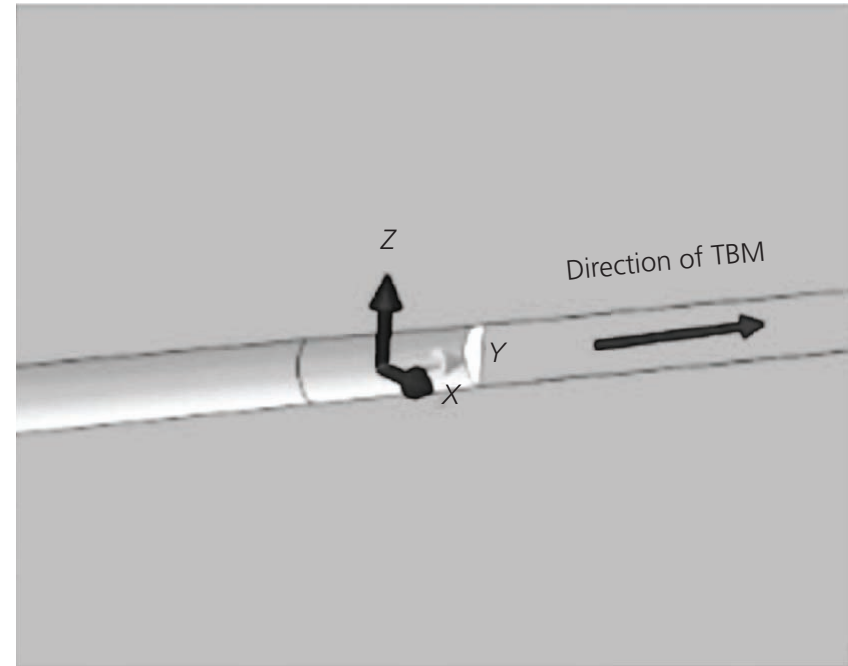

Figure 12. The local coordinates of the tunnel

have been normalised against the overburden to delete the effect of depth. It is extremely interesting to see the highest values of stress perpendicular to the tunnel $X$ around the overburdens $800-1100 \mathrm{~m}$, while the same stress is very low in correspondence with the maximum overburden. The average deviation of normal stress is maximum at the same overburden, and it is very low at the maximum overburdens.

The overcoring test results are plotted in Figure 15. It can be seen that the maximum principal stress is in the horizontal direction and normal to the tunnel axis. The medium and minimal principal stresses are generally on a plane that is parallel to the tunnel axis, and the angles of the medium and minimal principal stresses are

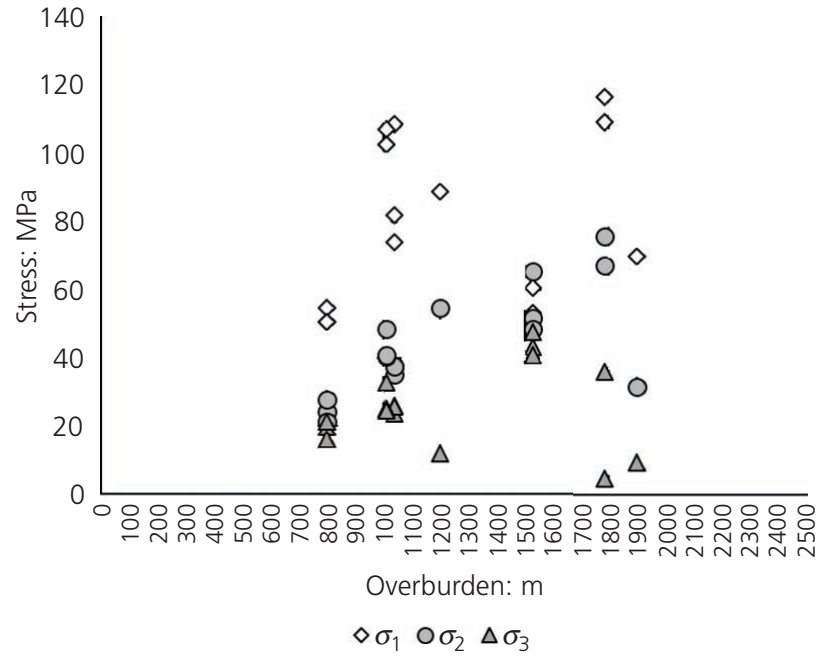

Figure 13. Magnitude of principal stresses along the tunnels plotted against overburden

varied from test to test. The direction of $\sigma_{1}$ can be regarded as horizontal and normal to the TBM tunnel axis; the direction of $\sigma_{2}$ can be regarded as parallel to the TBM tunnel axis; and the direction of $\sigma_{3}$ can be regarded as the vertical direction.

The orientations of the principal in situ stresses indicate that the in situ stresses are in the in-plane direction (a plane normal to TBM tunnel axis).

It is extremely interesting to analyse the maximum principal stress orientation along the tunnels. In Figure 16, the principal stresses are plotted in plan along the tunnels. It can be seen that the

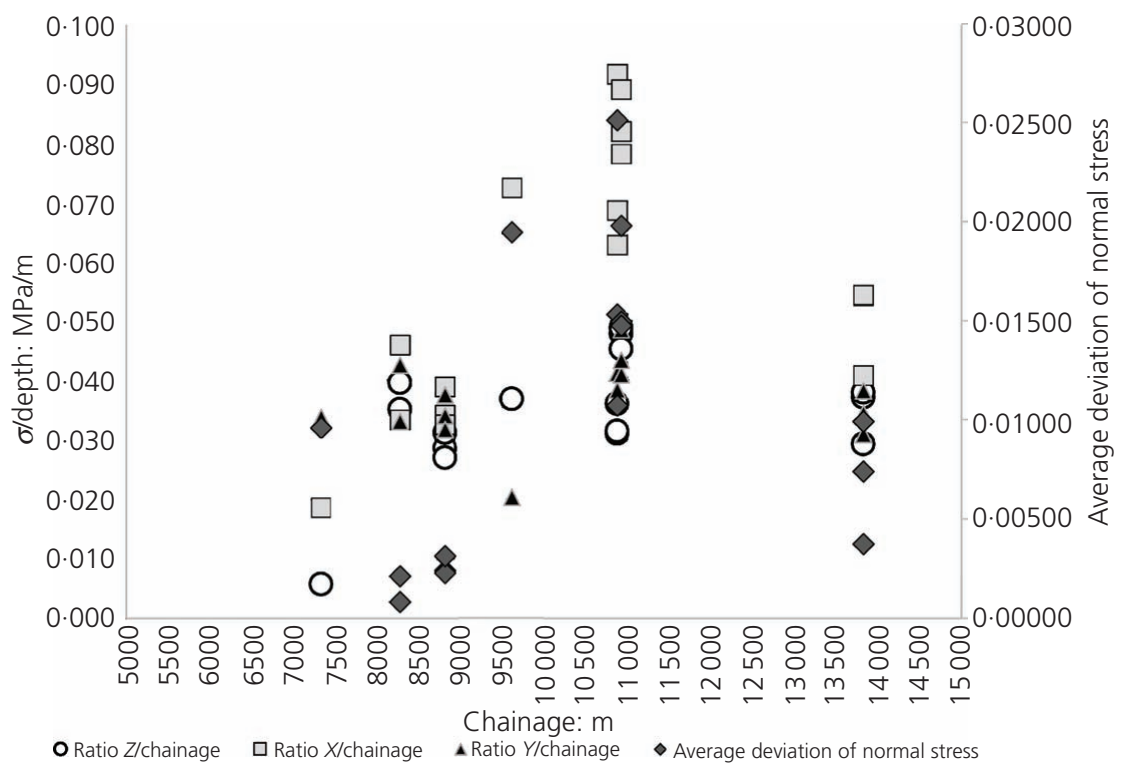

Figure 14. Normalised stresses plotted against chainage with overburden and average deviation of normal stress 


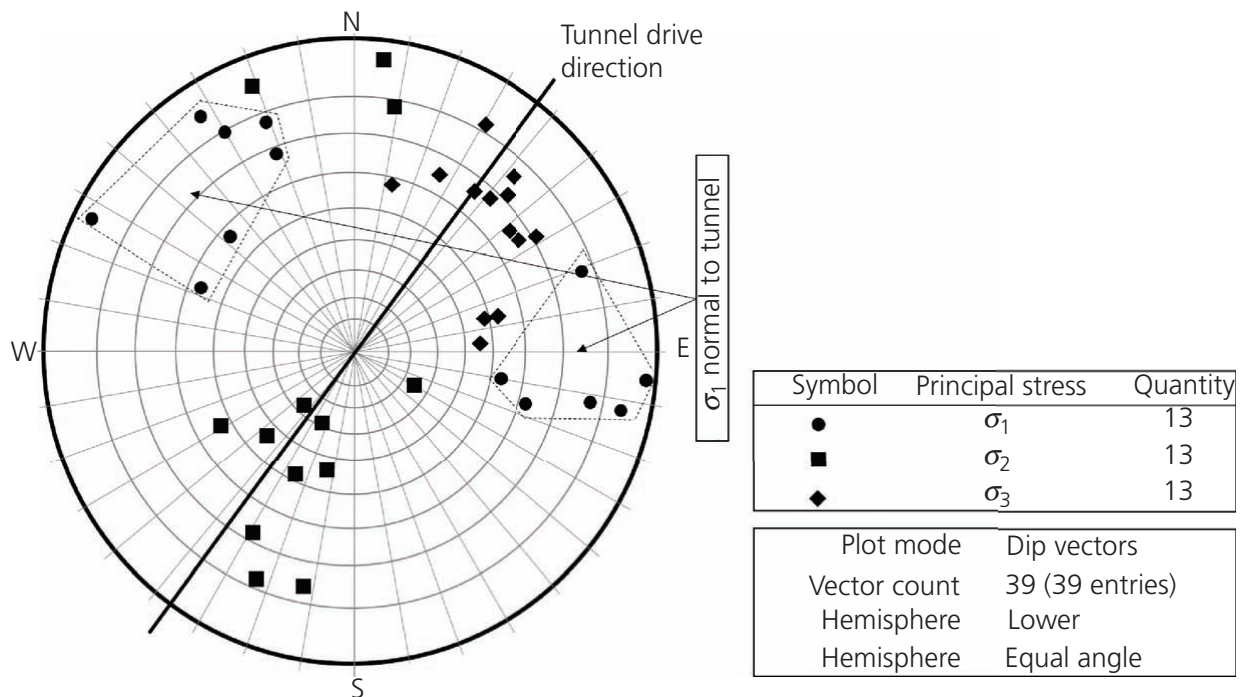

Figure 15. Pole plot showing direction of measured in situ stresses

principal stress direction is almost perpendicular to the alignment of the tunnels.

The project area exhibits both the regional thrust and the locally developed low-persistence faults. These thrust faults are typically associated with the Himalayan tectonic activity. In the project area, brittle materials such as sandstone facilitated the development of thrust faults.

The Muzaffarabad Fault, also known as the Himalayan Frontal Thrust, intersects the tunnel at a steep angle near the Jhelum River crossing. This fault has recently exhibited activity in the area, resulting in the catastrophic 2005 Muzaffarabad earthquake (Kaneda et al., 2008). The Muzaffarabad Fault has both strike-slip and thrust movements and is a system with several fault lines with a total width of $8 \mathrm{~km}$.
The distribution of in situ measurements along the tunnel is shown in Figure 17. It is extremely interesting to see that the overcoring tests carried out at the lower overburdens are internal to the Muzaffarabad Fault system.

Figure 18 shows the distribution of the stresses along the tunnel plotted against the chainage and overburden. It can be seen that the maximum stresses are not located at the maximum overburden as expected, but correspond to zones where the overburden is around $800-1100 \mathrm{~m}$. The rockburst events that occurred along the tunnels are shown with a star. It can be seen that the rockburst events occurred within the Muzaffarabad Fault system in correspondence with the maximum $X$ stress (in Figure 18, the $X$ stress is normalised against the overburden to cancel the effect of the depth), while the $X$ stress is minimum outside the fault zone in correspondence with the

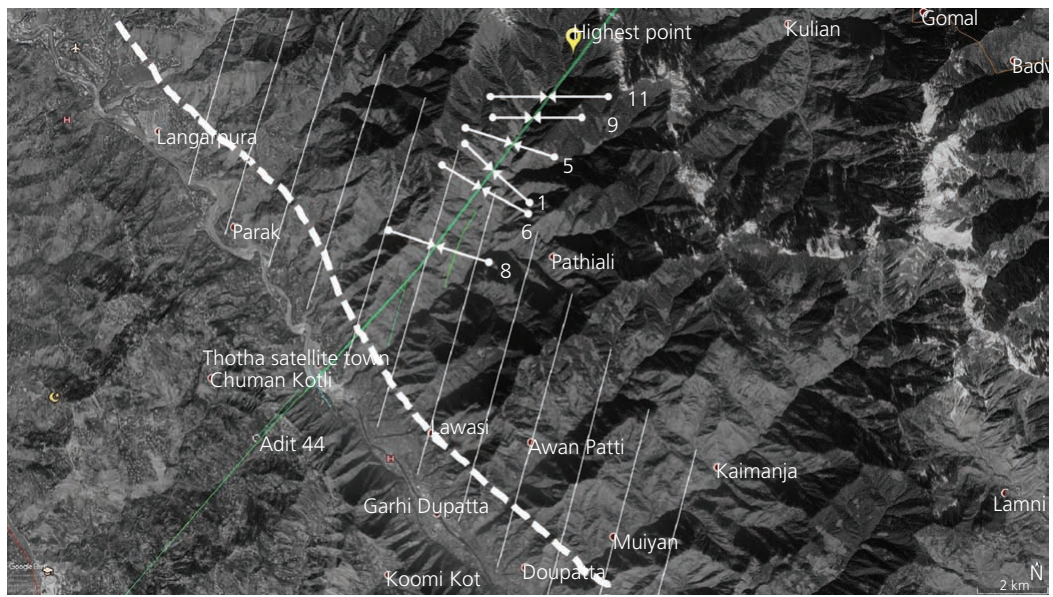

Figure 16. Principal stress direction along the TBM tunnels. White dots show the surface ruptures mapped by Kaneda et al. (2008). The white dashed area is the Muzaffarabad Fault system extension 


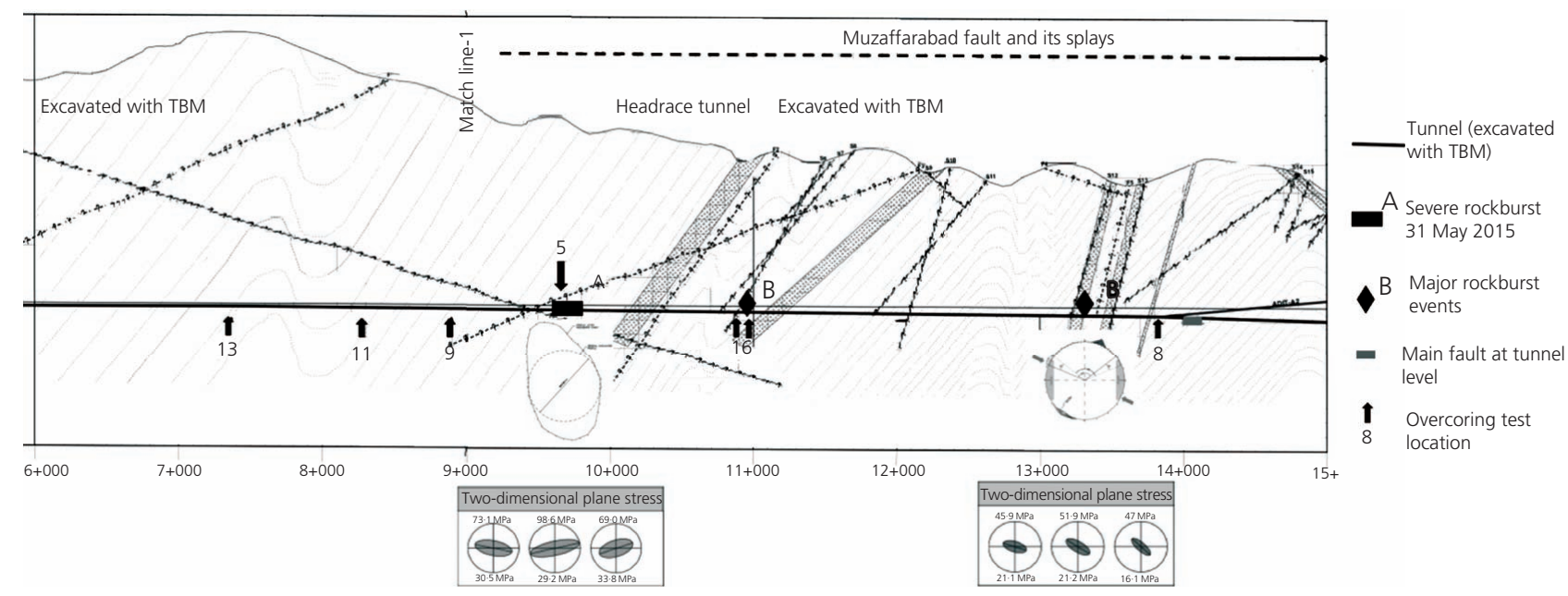

Figure 17. Main tectonic elements, rockburst events and in situ overcoring tests along the TBM tunnel. Only tests with complete results are reported

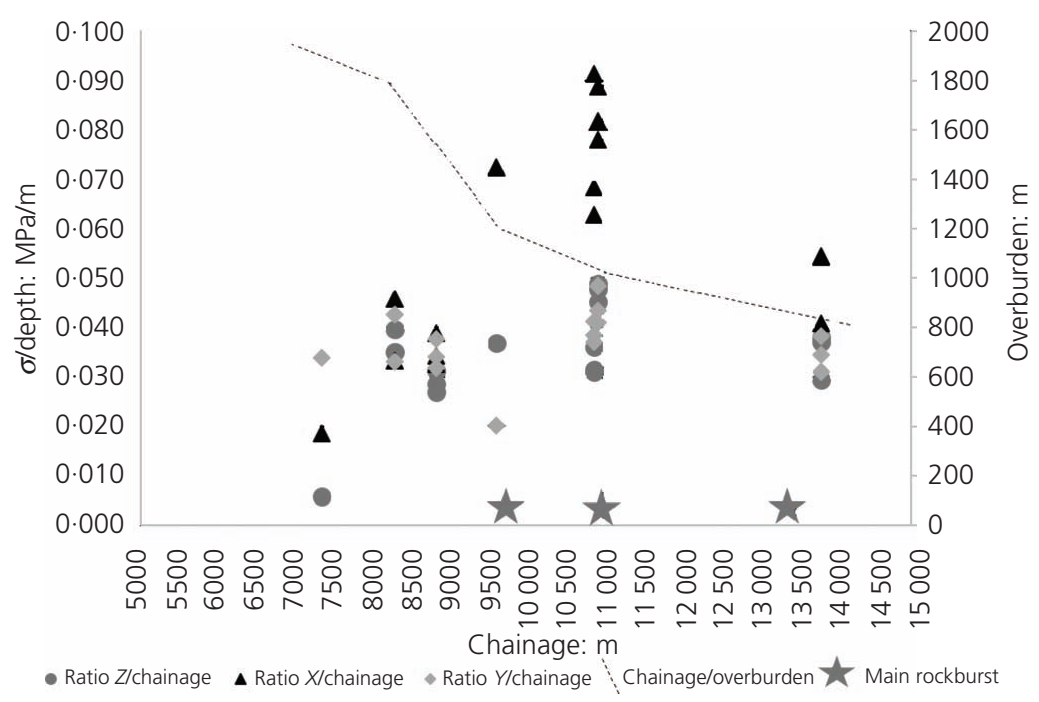

Figure 18. Normalised stresses against chainage and overburden at TBM tunnel. In this figure one can observe the very high stress along the $X$ axis at the lower depths due to tectonic stress not related to the normal stress. The rockburst events happened in correspondence with the maximum $X$ stresses, which do not correspond to the maximum overburden

maximum overburden, and the other components $Z$ and $Y$ are quite similar. The main stress on the $X Y$ plane (the lower part of Figure 17) shows a different orientation of the stress along the tunnel. These two-dimensional in-plane stresses are strongly related to the shape of the damage observed at the rockburst zones (Figure 19).

\section{Zone of elevated horizontal stress}

Figure 20 shows the extent of the TBM excavation and the distribution of the stresses after the overcoring test results. The zone of frequent rockbursts coincides with the zone with the maximum horizontal stress, which is, at the tunnel depth, the intersection with the Muzaffarabad Fault. The zone of the rockbursts incorporates the zone of frequent rockbursts, and the HI in situ stress measurements show that the presence of the tectonic area is predominant on the normal stress due to the overburden.

The microseismic monitoring has been extended to the maximum overburden area to prevent the rockbursts due to the normal stress, but in this area, the rockbursts were never severe such as those in the tectonic stress zone.

\section{Rockburst precautions and countermeasures}

The sandstone of the Murree Formation has more potential for rockburst compared with siltstone and mudstone. Approximately $80 \%$ of rockburst events, including severe rockbursts, were recorded from the sandstone beds at both TBMs. Thus, it was 


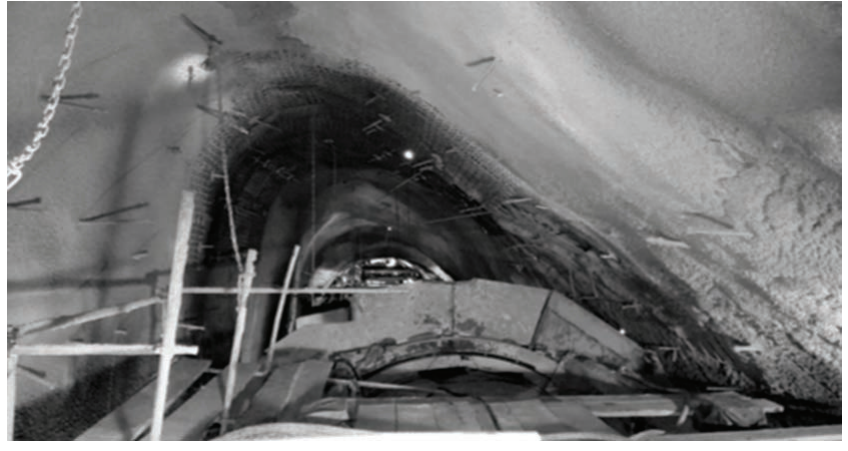

Figure 19. Rockburst zone between chainages 9+806 and 9+706 (zone $A$ in Figure 17). The image shows the orientation of maximum overbreak from 11 to five o'clock

important to identify the presence of sandstone ahead of the TBM. This was achieved by carrying out advance probe drilling up to $50 \mathrm{~m}$ in front of the TBM, and by analysing the return drilling waters, the grey-coloured sandstone would be identified.

Within the tight constraints of a TBM tunnel, there are limited options for dealing with potential rockburst. What measures are available can be divided into two categories.

\section{Preventative/reduction}

- Horizontal relief holes drilled in front of the TBM: these are same as a probe hole but drilled only into the sandstone bed and are multiple holes, typically $16 \mathrm{~m}$ drilled around to the top $260^{\circ}$ of the excavated tunnel.

- Vertical relief holes drilled behind the TBM shield: these are multiple vertical relief holes, typically $3 \mathrm{~m}$ drilled with the rock bolting drills over the upper $260^{\circ}$ of the excavated tunnel.
The aim of both horizontal and vertical stress relief holes is to induce cracking/fracturing of the sandstone, thereby eliminating or reducing the potential for rockbursts by pushing the stress deeper into the surrounding rock and away from the periphery of the excavated tunnel. Horizontal relief holes drilled over $260^{\circ}$ were extremely time consuming and could be carried out only while the TBM was stationary and not excavating, thus causing severe programme implications.

Vertical relief holes again would prevent the installation of tunnel support and would impact the tunnel programme.

\section{Reactive}

- Full circular steel rings: these are steel rings made up of eight segments clamped together to form a full continuous ring expanded to make full contact with the excavated tunnel profile. This is the strongest tunnel support installed. The spacing between adjacent steel rings can vary from 0.7 to $1.6 \mathrm{~m}$.

- Heavy-duty wire mesh: this mesh is installed between adjacent full steel rings and secured by rock bolts. This mesh prevents ejected rock from a rockburst coming into the TBM working area, thus protecting the TBM workforce. This would be installed over the upper $180^{\circ}$ of the excavated tunnel.

- Shotcrete applied behind the TBM shield: this would be installed by hand and again would prevent other support being installed such as rock bolts.

All the preventative measures were aimed at containing the impact of a rockburst which may or may not occur and would influence the overall tunnel programme. With the advent of regular rockbursts and the severe rockbursts of 31 May 2015, both preventative/reduction and reactive countermeasures were implemented on a daily basis, and the expected highest overburdens were still some $1 \cdot 1 \mathrm{~km}$ ahead of both TBMs.

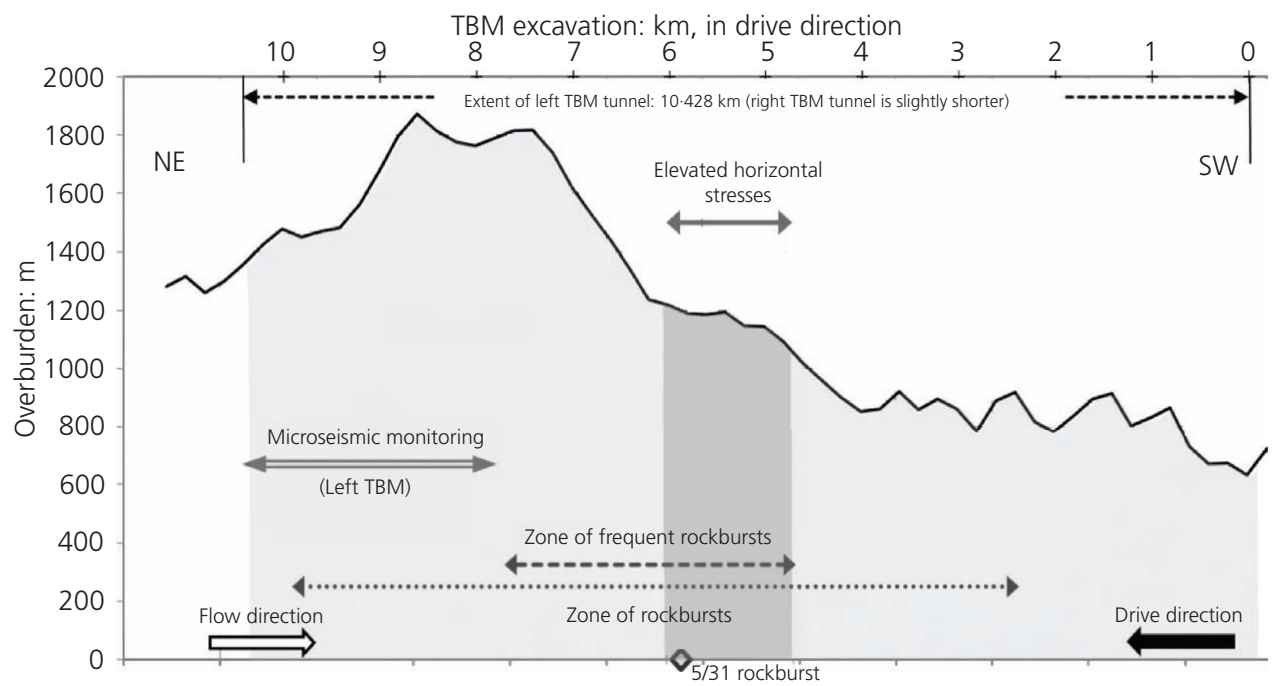

Figure 20. TBM tunnels with tectonic stress zone (courtesy of J. Mierjeweski) 


\section{Impact of overcoring test results on rockburst precautions and countermeasures}

The first significant impact of the overcoring test results was on the drilling of horizontal stress relief holes. With the indication of the higher horizontal stresses within the tunnel and the crossreferencing with the observed rockburst damage around the tunnel periphery, it was decided to reduce and be more precise with the locations of these stress relief holes. The number of holes was reduced from 18 in the upper $260^{\circ}$ of the excavated tunnel to eight in the upper $120^{\circ}$ slightly modified to the 11 to three o'clock position. This reduced the drilling time from $10 \mathrm{~h}$ down to $4 \mathrm{~h}$ and therefore increased TBM excavation time.

The second significant impact was on the vertical relief holes drilled directly behind the TBM shield. The targeted application, again in the 11 to three o'clock position, resulted in further time savings and increased the TBM excavation time.

The third significant impact was the indication from overcoring results at $7+440,7+339$ and $7+280$ that the zone of elevated horizontal stresses was coming to an end and that the installation spacing between full circular steel rings could start to increase from 0.7 to $1.6 \mathrm{~m}$.

These three significant findings resulted in a monthly production total of $180 \mathrm{~m}$ increasing over 3 months to $320 \mathrm{~m}$ per month.

\section{Conclusions}

Traditional systems for evaluating rockburst occurrence are too generic, and they only show the increase of risk with the overburden.

Since the first episode of rockburst occurred in the TBM tunnel, it was clear that more detailed information was necessary to understand and manage the rockburst risk.

It was decided to carry out in situ stress measurement to understand the stress distribution and magnitude and use this information in the prediction, prevention and control of rockburst.

In situ stresses are obtained in deep TBM tunnels by HI overcoring tests. Seventeen tests have been conducted successfully in seven boreholes. The tests carried out in five other locations have been refused due to the discing effect and presence of water, which have invalidated the results.

The results of the measurements show that the principal stress is very high and that the rockburst can occur everywhere along the tunnel.

The stress perpendicular to the tunnel shows very high values in correspondence with the lower overburden. This is related to the high tectonic stress on the rocks in the Muzaffarabad Fault area, where important movements have been observed after the disruptive earthquake in 2005 .
The stress orientation can be used to understand the rockburst position, and the magnitude of the measured stress can be used to identify the more dangerous sections along the tunnel but cannot help determine whether rockburst will happen.

To prevent and control the rockburst and its disruptive effects, a series of measures have been adopted taking into account of the location of the rockburst highlighted at the end of the tests.

\section{REFERENCES}

Diederichs MS, Carter T and Martin CD (2010) Practical rock spall prediction in tunnels. AITES/ITA Conference, Vancouver, BC, Canada.

Grimstad E and Barton NR (1993) Updating of the Q-system for NMT. In Proceedings of the International Symposium on Sprayed ConcreteModern Use of Wet Mix Sprayed Concrete for Underground Support (Kompen R, Opsahl OA and Berg K (eds)). Norwegian Concrete Association, Oslo, Norway, pp. 46-66.

Hoek E and Brown ET (1980) Underground Excavations in Rock. Institution of Mining and Metallurgy, London, UK.

Kaiser PK and McCreath DR (1993) Rock mechanics considerations for drilled or bored excavations in hard rock. Tunnelling and Underground Space Technology 9(4): 425-437.

Kaiser PK, Tannant DD and McCreath DR (1996) Canadian Rockburst Support Handbook. Geomechanics Research Centre, Laurentian University, Sudbury, ON, Canada.

Kaneda H, Nakata T, Tsutsumi H et al. (2008) Surface rupture of the 2005 Kashmir, Pakistan, earthquake and its active tectonic implications. Bulletin of the Seismological Society of America 98(2): 521-557, https://doi.org/10.1785/0120070073.

NGI (2015) Using the Q-system: Rock Mass Classification and Support Design. NGI, Oslo, Norway. See http://www.ngi.no (accessed 27/07/2018).

Nicksiar M and Martin CD (2013) Crack initiation stress in low porosity crystalline and sedimentary rocks. Engineering Geology 154: 64-76, https://doi.org/10.1016/j.enggeo.2012.12.007.

Norconsult (1997) Neelum-Jhelum Hydroelectric Project - Detailed Engineering Design Report. Norconsult, Sandvik, Norway, vol. I to IV. Worotnicki G and Walton RJ (1976) Triaxial hollow inclusion gauges (CSIRO) for determination of rock stresses in situ. Proceedings of the ISRM Symposium on the Investigation of Stress in Rock - Advances in Stress Measurements, Sydney, Australia, pp. 1-8.

\section{How can you contribute?}

To discuss this paper, please submit up to 500 words to the editor at journals@ice.org.uk. Your contribution will be forwarded to the author(s) for a reply and, if considered appropriate by the editorial board, it will be published as a discussion in a future issue of the journal. 